\title{
Association of Scabies Incidence with Sleep Quality of Students in Private Islamic Junior High School Shine Al-Falah, Padang
}

\author{
Nurhayati $^{1 *}$, Refi Amalia Utamai ${ }^{2}$, Satya Wydya Yenny ${ }^{3}$ and Nuzulia Irawati ${ }^{1}$ \\ ${ }^{1}$ Department of Parasitology, ${ }^{2}$ Medical Doctor Profession Program, \\ ${ }^{3}$ Depertment of Dermato Venerology, Faculty of Medicine, Andalas University, Indonesia
}

*Corresponding author

\section{A B S T R A C T}

Scabies is a contagious skin disease caused by an invasion of small parasite, Sarcoptes scabiei var hominis. Scabies causes itching symptoms, itching increases at night and can affect sleep quality. The purpose of this

Keywords

Scabies, sleep quality,

Sarcoptes scabiei var hominis

Article Info

Accepted: 15 June 2021 Available Online: 10 July 2021 study was to analyze the relationship between the incidences of scabies and sleep quality among students in Private Islamic Junior High School Shine Al Falah Padang City. This research was a cross sectional study. Primary data were used for diagnosis of scabies and the PSQI questionnaire measured the sleep quality of students. Analysis of data used the chi-square test for bivariate analysis. Statistical significance was determined if the $\mathrm{p}$ value was $<0.05(95 \% \mathrm{CI})$. This study was conducted to 80 students. Ten students(12.5\%) showed scabies infection, consisted of five boys and five girls. Most of students with scabies were about 13 years old. In this study, ten students with scabies had poor sleep quality. There was a significant relationship between the incidence of scabies and sleep quality of students ( $\mathrm{p}=0.000 ; 95 \% \mathrm{CI}$.). This study concluded that the incidence of scabies was closely related to sleep quality of students.

\section{Introduction}

Sleep is a subconscious condition when a person can be awakened by providing sensory stimuli. ${ }^{1}$ During sleep, various improvements occur in body functions, such as reparation of immune system, regulation of cytokines, and processing of brain metabolic waste. ${ }^{2}$ Two important aspects are involved in human sleeping; the quantity and quality of sleep. ${ }^{3}$ Sleep quantity is a number of time for a person needs to sleep according to his/her age. School-age children, among 6-12 years old, need 10 hours of sleep/day. Whereas, the hours of sleep decrease to 7-8.5 hours/day in adolescence. ${ }^{4}$ 
The second aspect affecting a person's sleep is sleep quality. The impact of good quality sleep is when a person gets fresh and healthy body after waking up. ${ }^{4}$ Psychological and physical disorders are factors which interfering a sleep quality. Heavy workloads, social demands, current psychiatric illnesses, and other disorder are parts of psychological disorder. ${ }^{5}$ Physical disorders such as pain and itching cause uncomfortable feelings when sleeping at night. ${ }^{4}$ Medicines are one of factors in disrupting sleep quality. ${ }^{5}$

A person who has a disturbance in sleep quality has a negative impact on health, mental, memory, and concentration. ${ }^{3}$ Impaired sleep quality in school-age children emerges mood disorder, neurocognitive disorder, and sleepiness during study hours, and finally the disorders affect negatively the academic grades of student ${ }^{2}$

Sleep disorder at night such as pain and itching is caused by various diseases, one of them is scabies. Scabies is a contagious skin disease caused by invasion and sensitization to Sarcoptes scabiei var hominis parasite and its products. ${ }^{6}$ Sarcoptes scabiei comes from Greek, sarx means skin, koptein means cut, and scabere means scratching. Sarcoptes scabiei is interpreted as itching of skin caused by mites and rose an activity of scratching the skin. $^{7}$

Scabies commonly occurs in developing countries with tropical climates, especially in environments with poor sanitation, poor health services, and in densely populated areas, such as in army barracks, detention centers, dormitories, orphanages and Islamic boarding schools. Scabies incidence is more risk for someone with a low socioeconomic level, poor personal hygiene, and bad habit of sexual relations such as promiscuous. ${ }^{6,8}$

The transmission of scabies is by skin-to-skin direct contact, hand shaking, sleeping together, and sexual intercourse. Indirect transmission is through bedding, clothes and towels. The transmission of scabies is relatively easy, this disease can spread to all people in a household, by making contact with the sufferer or with the sufferer's goods. ${ }^{6,8}$

Globally, scabies is estimated to affect more than 200 million people. ${ }^{9}$ According to the International Alliance for the Control of Scabiei, the incidence of scabies in different countries varies widely from $0.3 \%-46 \%$ of the population. ${ }^{10}$ The most vulnerable group to scabies is children. The estimated prevalence in children is $5-10 \%$ of all scabies incidence. ${ }^{11}$

In Indonesia (2008), scabies was in the third position of twelve most common skin diseases. ${ }^{8}$ Previous study conducted in several Islamic boarding schools in Indonesia showed that the incidence of scabies (2013-2016) was $24.6 \%-54.7 \%$ with an average age 15.11 years. Most of the sufferers were students in junior high school. The highest prevalence areas of scabies were Padang (24.6\%), Malang $(37.32 \%)$, Jakarta $(51.6 \%)$, and Yogyakarta $(54.7 \%)$. The percentage between women and men is almost similar. ${ }^{12}$ In 2018 , there were 48 patients diagnosed with scabies, consisted of 34 new cases and 14 old cases, who visited Skin and Genital Disease Polyclinic, M. Djamil Public Hospital. While, the incidence of scabies until May 2019 was 12 cases.

Scabies is characterized by symptoms of itching at night (Pruritus nocturna), formation of tunnels (cuniculus) at the site of predilection, finding mites on skin examination, and attacking a group of people who live in a dwelling place. The mite's activity on skin causes intense itching by increasing cellular and humoral immune response, emerges a feeling to scratch. Repeated scratching in an itchy area causes erosion, excoriation, crusting, and resulting in a secondary infection. ${ }^{6}$ Scabies is often considered a common occurrence in a 
dwelling, so it is rarely handled properly. In fact, secondary infection from Streptococcus pyogenes and Staphylococcus aureus increases as developing complications for bad handling of scabies. ${ }^{13}$

Itching at night causes discomfort and increasing the urge to continue scratching. This feeling makes a person difficult to start sleeping and wakes up frequently at night, which can cause sleep problems. This have an impact on decreased productivity and focus in the morning and during the day, because they cannot rest quietly. ${ }^{2}$

The effect of scabies is not only felt by sufferers, but also affect other people who live with them, because the transmission of scabies is very easy and fast. Islamic boarding schools are one of the places with risk for wide spreading scabies transmission due to frequent contact between students throughout the day.

In Padang, there are several Islamic boarding schools are at risk of scabies infection, due to poor environmental hygiene and high residential density. The Shine Al-Falah Islamic Boarding School is one of the Islamic boarding schools in Padang with the majority of students coming from the needy and orphans, with inadequate facilities. First investigation was found that the bedrooms were narrow and inhabited by many students. The distance between one student and another was very close when they sleep. In addition, the rooms have no sufficient ventilation, the air circulation was bad. The lighting was not enough, and the rooms were rather humid. The students sleep on cotton mattresses, the mattresses are rolled up after the students wake up in early morning, and extend again at bedtime. These environmental conditions tend to increase the transmission of scabies, both direct and indirect contact. The caregiver (who lives permanently at the Islamic boarding school) stated that many students complained of itching on the skin to purulence. This itching inhibited their daily activities and rest time. The study aimed to discover the relation of the scabies problem and sleep quality of student which has never been conducted at Shine Al-Falah Islamic Boarding School.

\section{Materials and Methods}

This study was observational analytic with cross sectional research design. The study was conducted from May 2019 to January 2020 at Shine Al-Falah Islamic Boarding School, Padang, West Sumatra. A total of 307 students were in class VII to IX. The student who eligible with inclusion criteria was involved in this study.

Inclusion criteria: student lives permanently at Shine Alfalah Islamic Boarding School, willingness to check-up and sign an inform consent. Exclusion criteria: student was infected by scabies and in the period of antiscabies treatment, other skin diseases with itching complaints, a history of insomnia before the occurrence of skin disorders, a history of severe and chronic diseases, symptoms with disturbing sleep quality, such as fever, pain (especially at night), and consuming anti-itch (anti-inflammatory) drugs, or sedative drugs (diazepam, lorazepam, etc.). Data were collected by anamnesis, examination for scabies diagnosis, and guided interviews using a questionnaire. The PSQI (Pittsburgh Sleep Quality Index) questionnaire was used to collect sleep quality data. ${ }^{14}$ The diagnosis of scabies was enforced by dermatologists and general practitioners to find cardinal signs of scabies; nocturnal pruritus, attacking in groups, cuniculus and mites. Scabies is enforced if 2 out of 4 cardinal marks are found. ${ }^{6}$

Analysis of data was assessed using chi square test, and data was significant statistically if $\mathrm{p}$ $<0.05$. This study has been approved by Ethics Committee of Medical Faculty, Andalas University number: 648/KEP/FK/2019. 


\section{Results and Discussion}

A total of 80 students of class VII to IX in Shine Al Falah Islamic Boarding School was eligible to this study.

Characteristics of respondents $(\mathrm{n}=80)$

A number of respondent in this study based on gender was similar $(n=40$, male and $n=40$, female). Most of student which participated was 13 years old $(n=37,46.25 \%)$.

Description of scabies incidence in Shine Al Falah Islamic Boarding School student

Table 2 described that the incidence of scabies was 10 students, consisted of five males and five females. Most of students was in 13 years old $(50 \%)$.

Based on questionnaire which applied in this study to discover the quality of sleep, 29 students had poor sleep quality (36.25\%), and 51 students with good sleep quality $(63.75 \%)$.

Relationship between scabies incidence and sleep quality in Shine Al Falah Islamic Boarding School

The Fisher's Exact Test obtained $\mathrm{p}$ value $=$ 0.000 ( $\mathrm{p}<0.05)$. The relationship between the incidence of scabies and sleep quality was statistically significant

The scabies examination conducted in 80 students of Shine Al Falah Islamic Boarding School found that $10(12.5 \%)$ students were positive for scabies. Previous study conducted by Khotimah suggested that the incidence of scabies in Al-Bahroniyyah Islamic Boarding School Ngemplak, Demak was $36.3 \%{ }^{15}$.Another study of scabies in Yogyakarta, the incidence of scabies was $54.7 \%{ }^{16}$. By comparing with previous studies, the incidence of scabies in Shine Al Falah Islamic Boarding School was lower. Although in early observation, many risk factors lead a person to develop scabies, such as poor ventilation, high occupancy density of bedroom (each room filled with 30-50 people), high humidity, cotton mattresses were rarely dried in the sun, and the high level of direct and indirect contact from mattresses and clothes that were often piled up.

Many factors influence the incidence of scabies in Islamic boarding schools; from the individual and from the environment. Individual factors involve level of knowledge, individual hygiene, attitude to hygiene awareness, and frequency of direct and indirect contact. Environmental factors that affect such as environmental cleanliness, air humidity, relatively hot room temperature, room ventilation, and high occupancy density $^{15,16,17}$.

The recent study found 10 people infected with scabies, five were females and five were males. These data indicated that there was no difference between the proportion of gender of males and females in the incidence of scabies. In line with study demonstrated in Health Care Centre, Lubuk Buaya, Padang, showed the ratio between males and females was 16 and 15 people. ${ }^{18}$ Another study conducted in Yogyakarta also showed that gender did not affect the incidence of scabies, and the comparison of gender (males and females) were $45.3 \%$ and $54.7 \% .^{19}$

Based on the results of this study, the highest incidence of scabies occurred at the age of 13 years. This result was similar to previous study conducted in Padang City showed that the highest incidence of scabies was at the age of $12-13$ years. ${ }^{20}$ It tent to occur in younger children. A lower level of understanding and experience of scabies were the main factor for scabies infection. In older children, the independence in maintaining personal hygiene is better than younger children. Personal hygiene in children is influenced by several 
factors including knowledge, attitudes and media access. ${ }^{21}$ Although there were difference range of age, but age was not statistically related to the incidence of scabies.

In this study, most of affected children were from grade seven of Shine Al Falah Islamic Boarding School. In line with a study in Padang, showed that the highest incidence of scabies was at grade seven. ${ }^{20}$ The lower the person's level of education, the lower of knowledge. ${ }^{22}$ At the 7 th grade level, students are new people in living in Islamic boarding schools, they try to adapt to the environment. The students have no experience about the risk of scabies occurred in crowded environments. Amajida and Sungkar also found that the incidence of scabies was greater at lower levels of education. ${ }^{23}$ But the differences of class level was not significantly associated with the incidence of scabies.

A total of 80 students as respondents, only 29 students $(36.25 \%)$ with poor sleep quality. In this study, out of ten people with scabies, all had poor sleep quality. The result was similar a study in Surakarta, showed $35.1 \%$ of students had poor sleep quality. ${ }^{24}$ In other study in Lampung found that Islamic boarding school students tent to have poor sleep quality, the most influencing factor was the duration of sleep for all students $<5$ hours/day. ${ }^{25}$ The quality of sleep was affected by emotional stress and the environment surrounding them. Stress emerged due to many factors; unfamiliar situation of the dormitory environment, separated away from parents, fear of academic grades result and disappointing parents, regular recitation, a busy daily activity schedule, and even crying at night because feeling tired during stay at the dormitory. Environments influenced sleep quality, such as the distance of sleeping between students was close and crowd, uncomfortable feeling due to high temperature and humidity in bedroom, hard mattresses, etc. ${ }^{26}$ Inearly observations, several factors were found in the student's dormitories, and to lead poor sleep quality for the students.

Based on Fisher's Exact Test, the result showed that there was a significant relationship between the incidence of scabies and sleep quality with $\mathrm{p}$ value $=0.000(\mathrm{p}$ $<0.05)$. Rienda ${ }^{27}$ also found that there was a significant relationship between the incidence of scabies and sleep quality.

Scabies is not a direct cause of sleep disturbances, because sleep disturbances can be multifactorial. However, scabies causes symptoms of nocturnal pruritus or itching especially at night. Itching at night is caused by mites that are more active in digging tunnels at night, so itching is more dominant at night. The residue of dead mite also stimulates an immune response that causes itching. Itching at night is closely related to a person's circadian rhythm to sleep.

Physiological changes in the skin such as skin temperature and skin defense function that occur at night exacerbate nocturnal pruritus. These symptoms interfere with the patient's sleep activities at night and will lead to poor sleep quality. ${ }^{28}$ Symptoms of sleep disorder have an impact on fatigue and excessive sleepiness during the day, so that a person is discouraged and decreased concentration which is mainly complained of by school-age children. $^{28}$

The incidence of scabies in Shine Al Falah Islamic Boarding School was $12.5 \%$ with the majority aged of 13 years. All students who suffer from scabies have poor sleep quality. There was a significant relationship between the incidence of scabies and the sleep quality of students in Shine Al Falah Islamic Boarding School, Padang City. 
Table.1 Distribution of student's characteristic of Shine Al Falah Islamic Boarding School

\begin{tabular}{|c|c|c|c|}
\hline S.No & Student's Characteristic & $\mathbf{n}$ & $\mathbf{\%}$ \\
\hline 1. & Gender: a. Male & 40 & 50 \\
\hline & b. Female & 40 & 50 \\
\hline & Total & 80 & 100 \\
\hline 2. & Age: a. 12 years & 11 & 13.75 \\
\hline & b. 13 year & 37 & 46.25 \\
\hline & c. 14 years & 15 & 18.75 \\
\hline & d. 15 years & 13 & 16.25 \\
\hline & e. 16 years & 4 & 5.00 \\
\hline & Total & 80 & 100 \\
\hline
\end{tabular}

Table.2 Distribution of scabies frequency by gender and age of students

\begin{tabular}{|c|c|c|c|}
\hline S.No & Scabies incidence & $\mathbf{n}$ & $\mathbf{\%}$ \\
\hline 1. & Gender: a. Male & 5 & 50 \\
\hline & b. Female & 5 & 50 \\
\hline & Total & 10 & 100 \\
\hline 2. & Age: a. 12 years & 3 & 30 \\
\hline & b. 13 year & 5 & 50 \\
\hline & c. 14 years & 1 & 10 \\
\hline & d. 15 years & 1 & 10 \\
\hline & Total & 10 & 100 \\
\hline
\end{tabular}

Fig.1 Description of scabies incidence in Shine Al Falah Islamic Boarding School. A total of 80 students which participated in this study, $87.50 \%(\mathrm{n}=70)$ students were negative to scabies and $12.50 \%(\mathrm{n}=10)$ students were positive

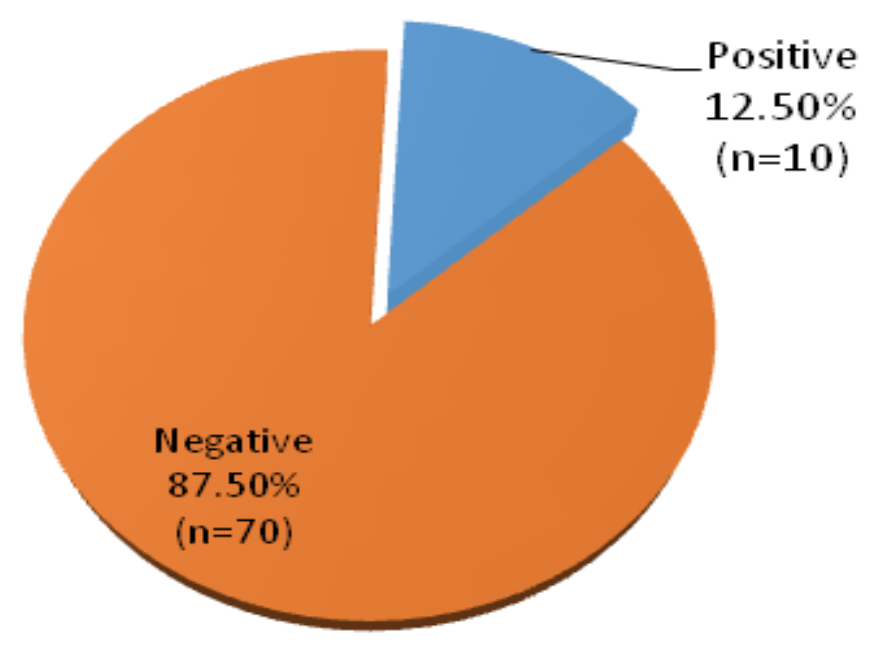


Table.3 Relationship between the incidences of scabies and sleep quality of respondents

\begin{tabular}{|c|c|c|c|c|c|c|c|}
\hline \multirow[t]{3}{*}{ Scabies } & \multicolumn{4}{|c|}{ Sleep quality } & \multirow{2}{*}{\multicolumn{2}{|c|}{ Total }} & \multirow{3}{*}{$\begin{array}{c}* p \\
\text { value }\end{array}$} \\
\hline & \multicolumn{2}{|c|}{$\mathrm{Bad}$} & \multicolumn{2}{|c|}{ Good } & & & \\
\hline & $f$ & $\%$ & $f$ & $\%$ & $f$ & $\%$ & \\
\hline Without scabies & 51 & 63.75 & 19 & 23.75 & 70 & 100 & 0.000 \\
\hline Scabies & 0 & 0 & 10 & 12.50 & 10 & 100 & \\
\hline Total & 51 & 63.75 & 29 & 36.25 & 80 & 100 & \\
\hline
\end{tabular}

*Fisher's Exact Test

Fig.2 Sleep quality performance of students in Shine Al Falah Islamic Boarding School.

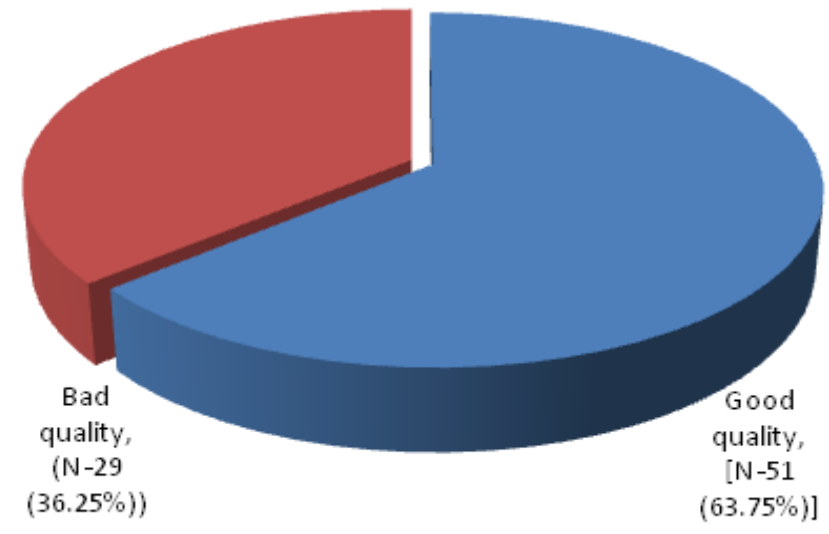

\section{Acknowledgments}

The authors thank to all people who have helped the completion of this study, especially for staffs of Department of Parasitology, Andalas University, Dr.TuttyAriani, Sp.DV, staffs of Dermato Venerology Department in M.Djamil Hospital, and students, headmaster and teachers of Shine Al Falah Islamic Boarding School.

\section{Funding}

This study was supported by private funding, as a form of community dedication program from university to society.

\section{References}

1. Guyton A C, Hall J E. Buku Ajar Fisiologi Kedokteran. 11th ed. Irawati RDIF, editor. Jakarta: BukuKedokteran EGC; 2006.

2. Lavery $M$ J, Stull $C$, Kinney $M \quad O$, Yosipovitch G. Nocturnal Pruritus: The Battle for a Peaceful Night's Sleep. Int J Mol Sci. 2016;425(17):513-5

3. Fenny, Supriatmo. HubunganKualitas Dan Kuantitas Tidur Dengan Prestasi Belajar Pada Mahasiswa Fakultas Kedokteran. J Pend Ind. 2016;5(3):1-8.

4. Alfi W N, Yuliwar R. Hubungan Kualitas Tidur Dengan Tekanan Darah Pasien Hipertensi. J Epid Ind. 2018;6(1):18-26.

5. Lo C, Lee P. Prevalence and impacts of poor sleep on quality. BioMedCentrl. 2012;72(10):1-7.

6. Boerdiarja S, Handoko R. Ilmu Penyakit Kulitdan Kelamin. 5th ed. Jakarta: Fakultas Kedokteran Universitas Indonesia; 2015.

7. Setyaningrum Y I. Skabies Penyakit Kulit yang Terabaikan: Prevalensi Tantangandan Pendidikansebagai Solusi Pencegahan Surakarta: Biologi FKIP Universitas Sebelas Maret; 2013.

8. Mading, Indriaty I. Kajian Aspek Epidimiologis kabies pada Manusia. J Kes Bersumber Binatang. 2015;2(2):1-4.

9. WHO (2018). Negleted tropical disease: Scabies. World Health Organization. 
https://www.who.int/neglected_diseases/disea ses/scabies/en/. -- Diakses 13 Mei 2019

10. IACS(2019). Scabies. International Alliance for the Control of Scabies. http://www.controlscabies.org/about-scabies. -- Diakses 13 Mei 2019

11. Hay RJ, Steer AC, Engelman D, Walton S. Scabies in the developing world: its prevalence, complications, and management. IntFon for DermLond. 2012;18(1):313-23.

12. Tresnasari C, Triyani Y, Respati T, Tejasari M, Kharisma Y, Maulida M. Understanding Scabies in Religious Boarding School (Pesantren). Ed and Hum Resc. 2018;307(2):1-3.

13. Engelmann. Control Strategies for Scabies. Trop Med Inf Dis. 2018;98(3):1-3.

14. Jumarni. Comparison of Sleep Quality by Pittsburgh Sleep Quality Index (PSQI)Scale in Anxiety Disorder Patient using Long Term and Short Therm Benzodiazepines Therapy Makassar: Universitas Hassanudin; 2018.

15. K K K. Hubungan Sanitasi Lingkungandan Hygiene Perorangandengan Kejadian Skabies di Pondok Pesantren Al-Bahroniyyah Ngemplak Mranggen Kabupaten Demak. Jurnal Kesehatan UNDIP. 2013;6(1):5-9

16. Hilman G. Faktor-faktor yang memengaruhi Kejadian Skabies di Pondok Pesantren Mlangi Nogotirto Gamping Sleman, Yogyakarta. JKKI. 2014;6(3):2-7

17. Ibadurrahmi H. Faktor-Faktor Yang Berpengaruh Terhadap Kejadian Penyakit Skabies Pada Santri Di Pondok Pesantren Qotrun Nada Cipayung Depok Februari Tahun 2016. JurnalProfesiMedika ISSN. 2016;10(1):12-6

18. Yunita S, Gustia R, Anas E. Faktor-faktor yang Berhubungandengan Kejadian Skabies di Wilayah Kerja Puskesmas Lubuk Buaya
Kota Padang Tahun 2015. Jurnal Kesehatan Andalas. 2018;7(1):23-9

19. Hilma U, Ghazali L. Faktor-faktor yang Memengaruhi KejadianSkabies di Pondok Pesantren Mlangi Nogotirto Gamping Sleman Yogyakarta. JKKI. 2014;6(3):54-8

20. Akmal,Akmal S, Semiarty R, Gayatri. Hubungan Personal Hygiene Dengan Kejadian Skabies Di Pondok Pendidikan Islam Darul Ulum, Palarik Air Pacah, Kecamatan Koto Tangah Padang Tahun 2013. Jurnal Kesehatan Andalas. 2013; 2(3):4-8

21. Triasmari U, Andiko N. Determinan Personal Hygiene Pada Anak Usia 9-12 Tahun. Faletehan Health Journal. 2019;6(1):58-63

22. Notoatmodjo S. Ilmu Perilaku Kesehatan Jakarta: P T Rineka Cipta; 2007.

23. Amajida F, Sungkar S. Prevalensi Skabiesdan Faktor-faktor yang Berhubungan di Pesantren X, JakrtaTimur. eJKI. 2014; 2(1):1-5

24. Fahmi A, Priyadi N. Faktor-Faktor yang Berhubungan Dengan Perilaku Pola Tidur Santri Kelas XI MA Pondok Pesantren Modern Islam Assalam Surakarta. Jurnal Kesehatan Masyarakat. 2016;4(5):299-309.

25. Gina P, dian 1, Setyowati A. Stresdengan kualitastidurpadaremaja. Dunia Keperawatan. 2018;6(2):107-115.

26. M U. Hubungan Stres Akademikdengan Kualitas Tidur Pada Siswa Pondok Pesantren. JKII. 2017; 8(3).

27. Monica R. Hubungan Infestasi Skabies Dengan Kualitas Tidur Pada Anak Di Panti Asuhan Kemiling Bandar Lampung (Skripsi) Lampung: FakultasKedokteran UNILA; 2017.

28. AnnisaR(2016). Hubunganantarask abiesden gankualitas tidur di pondok pesantrenmifta khurrosyidin.

\section{How to cite this article:}

Nurhayati, Refi Amalia Utama, Satya Wydya Yenny and Nuzulia Irawati. 2021. Association of Scabies Incidence with Sleep Quality of Students in Private Islamic Junior High School Shine Al-Falah, Padang. Int.J.Curr.Microbiol.App.Sci. 10(07): 275-282.

doi: https://doi.org/10.20546/ijcmas.2021.1007.029 